\title{
Persistence of an introduced mudflat community in South San Francisco Bay, California
}

\author{
Frederic H. Nichols \& Janet K. Thompson
}

U.S. Geological Survey, 345 Middlefield Road MS-999, Menlo Park, California 94025, USA

\begin{abstract}
The benthic invertebrate community inhabiting the extensive and sedimentologically homogeneous mudflats of South San Francisco Bay has demonstrated a high degree of constancy in both species composition and relative abundance among species throughout $10 \mathrm{yr}$ of observation. The community, composed predominantly of introduced species with opportunistic lifestyles, is dominated numerically by Gemma gemma, Ampelisca abdita, and Streblospio benedicti. The key to the persistent co-occurrence of these species on the mudflats seems to lie in the combination of (1) the recurrence of minor disturbances of the mudflat habitat (e.g. sediment deposition/erosion, inundation by low-salinity water) on time scales comparable to that of life cycles; (2) opportunistic life history strategies (rapid maturity, brooding of young, multiple generations each year, ease of local dispersal of both juveniles and adults) that permit continued colonization of the mudflat surface or rapid recolonization after disturbances. Only 1 of the 3 numerically-dominant species, A. abdita, displays an annual periodicity in abundance. $S$. benedicti and $G$. gemma, through broadly flexible reproductive strategies permitted in the mild San Francisco climate, can exhibit strong recruitment at any time between spring and autumn. The most extreme community changes, involving temporary reduction or elimination of normally dominant populations, occurred as a result of anomalous disturbances such as unusual buildup and decay of an algal mat during 1 summer and prolonged periods of unusually high freshwater inflow during 2 successive winters. The introduced opportunists routinely co-occur at high densities. However, one of these, the tube-dwelling amphipod A. abdita, may control the abundance of the native mollusk Macoma balthica.
\end{abstract}

\section{INTRODUCTION}

Multi-year investigations of estuarine benthos have shown that seasonal variations in species abundance, reflecting annual cycles of reproduction and mortality (e.g. Watling 1975, Holland et al. 1977, Whitlatch 1977. Diaz 1984), can be greatly overshadowed by interannual variations, particularly those associated with habitat disturbances (e.g. Boesch et al. 1976b, Pearson \& Rosenberg 1978, Sanders et al. 1980, Beukema 1982, Boesch \& Rosenberg 1982). Large-scale disturbances of soft-bottom benthic communities take many forms, but the best documented natural perturbations are those associated with unusual climatic events or cycles (Eagle 1975, Boesch et al. 1976a, Buchanan et al. 1978, Ziegelmeier 1978, Beukema 1979). Small-scale disturbances take the form of physical disturbances by predators (including birds, fish, rays, as well as other invertebrates) and localized erosion or deposition (e.g. Levin 1984a).

The typical response to a disturbance, wherein at least some species populations are locally reduced or eliminated, involves a sequence of changes in community taxonomic composition including initial exploitation of the disturbed area by opportunists. Such species respond, through high reproductive capacity, rapid maturity and ease of dispersal, to the availability of underexploited substrate (e.g. McCall 1977) and released resources (e.g. Thistle 1981, VanBlaricom 1982). The opportunists, subject to high mortalities (Grassle \& Grassle 1974), are subsequently displaced in a successional process that leads to the return of resident species (McCall 1977, 1978). The process is affected markedly by the timing and intensity of the disturbance (Zajac \& Whitlatch 1982a,b), and the result is a dynamic community structure that, at any instant, reflects the recent history at the site (Sutherland 1974).

The cumulative results of numerous studies of the benthos of San Francisco Bay (e.g. Filice 1958, Painter 1966, Storrs et al. 1966, Vassallo 1969, Liu et al. 1975, Nichols 1977, 1979, Kinnetic Laboratories Inc. 1981) reveal that the invertebrate assemblages of the broad, 


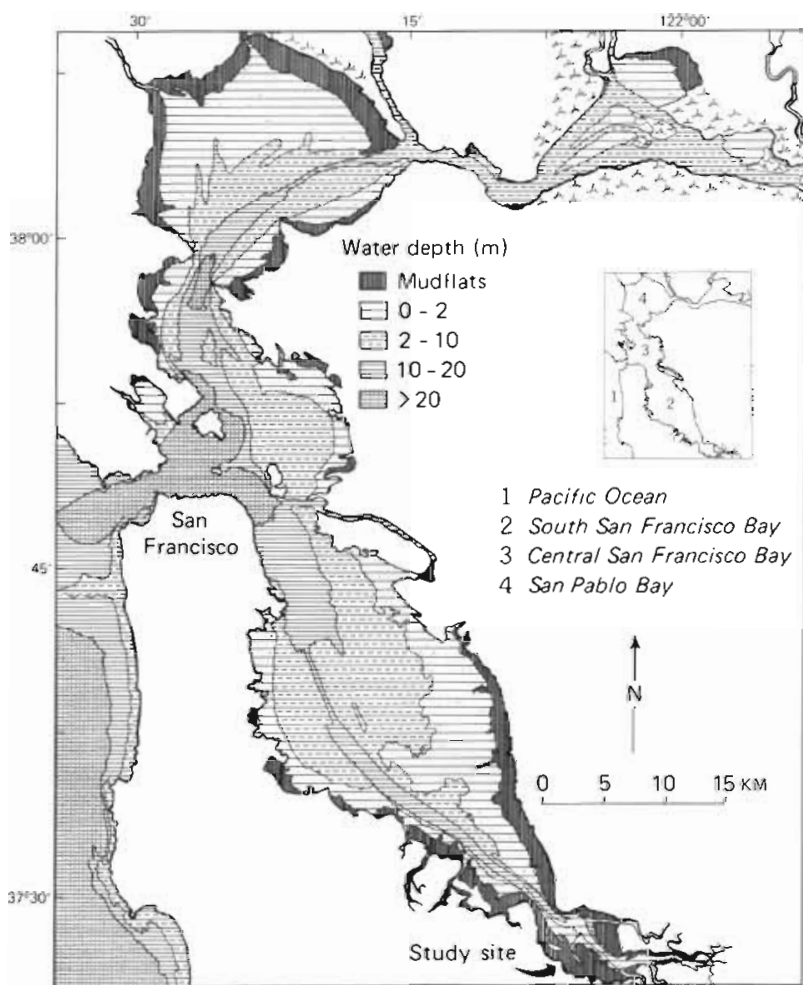

Fig. 1. San Francisco Bay, with an inset showing the location of sub-bays. Arrow points toward the location of our study site near the southern end of the bay. Intertidal mudflats, up to a $\mathrm{km}$ or more wide at low tide, represent more than $15 \%$ of Bay area exclusive of marshes; shallow subtidal mud bottom to $2 \mathrm{~m}$ depth represents another $30 \%$

shallow, muddy reaches of San Pablo and South San Francisco Bays (45\% of San Francisco Bay is less than $2 \mathrm{~m}$ deep) are composed in large part of the same few species in the same relative abundances. Moreover, most of these species were accidentally or intentionally introduced since the mid-1800's as fouling, boring and ballast-dwelling organisms on ships or in shipments of oysters transplanted from the east coast of the United States and Japan for growing in the bay (Carlton $1979 \mathrm{a}, \mathrm{b})$. These species represent the vast majority of specimens (Nichols 1979) and $>95 \%$ of the total biomass (Nichols unpubl. data). Those that occur in highest densities are small short-lived species with rapid maturity, high fecundity, and flexible dispersal strategies - lifestyles that characterize opportunistic species. In short, a benthic community composed largely of introduced opportunists is a striking and permanent feature of San Francisco Bay.

The overwhelming success of introduced opportunists poses interesting questions: (1) what has allowed these few species to predominate in the vast shallow mud areas of San Francisco Bay; (2) how are they maintained in permanent populations; (3) what has been the role (and fate) of any native species that may have once occupied these habitats?
We have examined, over a 10 yr period, the species composition and abundance in the macroinvertebrate community of a South San Francisco Bay mudflat (Fig. 1) in an attempt to identify those factors that contribute to short-term variations in abundance and long-term maintenance of the community. Particular emphasis has been placed on evaluating the importance to community structure of (1) natural physical and chemical disturbances of the Inudflat habitat (e.g. intermittent sediment erosion and deposition, seasonal and interannual variations in fresh-water inflow), and (2) the possible interaction among species.

\section{METHODS}

Sample collection. Three replicate $57 \mathrm{~cm}^{2}$ core samples were collected at each of 3 stations monthly or bimonthly for $3 \mathrm{yr}$ beginning in 1974, semi-annually through 1981, and quarterly since. Stations were located in soft mud ( $<20 \%$ sand by weight) at 12,28 and $142 \mathrm{~m}$ distance along a transect normal to the seaward edge of a Spartina foliosa/Salicornia pacifica salt marsh and at about 110,90 , and $80 \mathrm{~cm}$ above MLLW respectively. These stations are hereafter referred to as upper, middle, and lower respectively. Station description and sampling methodology have been described elsewhere (Nichols 1977). One replicate sample was analyzed at the middle and lower stations after late 1977 and at the upper station after late 1978. Additionally, single $165 \mathrm{~cm}^{2}$ samples were collected monthly or bimonthly at the upper station between June 1979 and January 1982. Samples were washed on a $0.5 \mathrm{~mm}$ screen, and specimens were identified to species with the exception of a few species for which the specific name is in question (Table 1). Data from this study are available elsewhere (Thompson \& Nichols 1984). During the first 3 yr of our study elevation of the mudflat surface was measured at the 3 Stations (Nichols 1979, Thompson 1982).

Numerical analysis. Similarity among species and sampling dates at each station was determined from log-transformed data using the Czekanowski Quantitative Index (Bray \& Curtis 1957, Bloom 1981). Both normal (similarity among sampling dates using species as attributes) and inverse (similarity among species using sampling dates as attributes) classifications were performed on the data. All species were included in the normal classification, whereas species occurring in 4 or fewer samples were eliminated in the inverse analysis to reduce the possibility of misclassifications due to rare species. Cluster analysis was carried out using the group-average sorting strategy (Sneath \& Sokal 1973, Boesch 1977). Calculations and plots were made using the program ORDANA (Bloom et al. 1977) 
modified for use on a VAX-11/750 computer (4.2 BSD Unix operating system). Nodal constancy diagrams were constructed from the inverse and normal classification output to examine coincidence between species and sampling date clusters (Boesch 1977).

Kendall's coefficient of concordance, W (Siegel 1956), was calculated for each station to determine similarity of species rankings among sampling dates at each station. Tied observations were assigned the average rank.

To determine whether abundance fluctuations oc- curred simultaneously for a given species at all stations, or between species at each station, a crosscorrelation analysis with zero time lag was used (Bendat \& Piersol 1971). To test whether a consistent annual cycle was present in the abundance of a given species, the 10 yr data were fitted to a sinusoidal curve with adjustable phase and a length of 1 yr using a leastsquares regression. Significance of fit of data to a repeating annual curve was confirmed if the amplitude of the curve was significantly different from zero (Brownlee 1965).

Table 1. Macrobenthic species on a South San Francisco Bay mudflat. Introduced versus native status of each species (with references): n: native; i: introduced; i?: possibly introduced; ?: not determined. Relative abundance of each species: ${ }^{\cdot}$ common; $\cdots$ uncommon (seen frequently but in small numbers and not consistently); $\cdots$ rare (seen occasionally)

\begin{tabular}{|c|c|c|c|}
\hline Species & Status & Status reference & Comments \\
\hline \multicolumn{4}{|l|}{ ANNELIDA } \\
\hline Harmothoe imbricata $\cdots$ & n & & \\
\hline Eteone californica. & i? & Carlton 1979b; Pettibone 1954 & Probably E. longa \\
\hline Sphaerosyllis sp. $"$ & i? & Nichols unpubl. & Probably S. erinaceus \\
\hline Nereis succinea & $i$ & Carlton $1979 \mathrm{~b}$ & \\
\hline Glycinde sp. ‥ & $n$ & & G. armigera/polygnatha \\
\hline Marphysa sanguinea... & i & Carlton $1979 b$ & \\
\hline Polydora ligni. & $\mathrm{i}$ & Carlton $1979 \mathrm{~b}$ & \\
\hline Pseudopolydora kempi". & $\mathrm{i}$ & Carlton $1979 \mathrm{~b}$ & \\
\hline Pygospio elegans".." & $\mathrm{n}$ & & \\
\hline Streblospio benedicti & $i$ & Carlton $1979 \mathrm{~b}$ & \\
\hline Tharyx sp. . & $?$ & & \\
\hline Chaetozone sp. $\cdots$ & $?$ & & \\
\hline Capitella capitata'.. & $\mathrm{i}$ & Carlton $1979 b$ & Possibly sibling species \\
\hline Heteromastus filiformis ${ }^{*}$ & $\mathrm{i}$ & Carlton $1979 b$ & \\
\hline Tubificoides brownae" & $?$ & & \\
\hline Limnodriloides monothecus ${ }^{\circ}$ & $?$ & & \\
\hline Oligochaeta spp. $\cdots$ & $?$ & & \\
\hline \multicolumn{4}{|l|}{ CRUSTACEA } \\
\hline Ampelisca abdita & i & Carlton $1979 \mathrm{a}, \mathrm{b}$ & $=A \cdot$ milleri \\
\hline Corophium acherusicum ${ }^{*}$ & i & Carlton $1979 a, b$ & \\
\hline Corophium insidiosum ${ }^{*}$ & $\mathrm{i}$ & Carlton $1979 a, b$ & \\
\hline Corophium spp." & $\mathrm{i}$ & & Unident. females \\
\hline Grandidierella japonica" & i & Chapman \& Dorman 1975 & \\
\hline Cyprideis sp. & $?$ & & \\
\hline Sarsiella zostericola ${ }^{\circ}$ & $\mathrm{i}$ & Kornicker 1975 & \\
\hline Balanus improvisus $\cdots$ & $\mathrm{i}$ & Carlton $1979 b$ & \\
\hline Cumella vulgaris $\cdots$ & $?$ & & \\
\hline Tanais sp. $\cdots$ & $\mathrm{i}$ & Carlton $1979 \mathrm{~b}$ & \\
\hline Synidotea laticauda $\cdot$ & $\mathrm{i}$ & Carlton $1979 a, b$ & \\
\hline \multicolumn{4}{|l|}{ MOLLUSCA } \\
\hline Boonea bisuturalis & i & Carlton $1979 \mathrm{a}, \mathrm{b}$ & $=$ Odostomia $=$ Menestho \\
\hline Ilyanassa obsoleta." & $\mathrm{i}$ & Carlton 1979a, b; Hanna 1966 & \\
\hline Urosalpinx cinerea. & $\mathrm{i}$ & Carlton 1979a, b; Hanna 1966 & \\
\hline Gemma gemma. & $\mathrm{i}$ & Carlton $1979 a$, b; Hanna 1966 & \\
\hline Macoma balthica. & $\mathrm{n}$ & Carlton $1979 \mathrm{a}, \mathrm{b}$ & \\
\hline Musculista senhousia.. & i & Carlton 1979a, b; Hanna 1966 & $=$ Musculus \\
\hline Mya arenaria & $\mathrm{i}$ & Carlton 1979a, b; Hanna 1966 & \\
\hline \multicolumn{4}{|l|}{ CNIDARIA } \\
\hline Anthozoa $\cdots$ & $?$ & & \\
\hline \multicolumn{4}{|l|}{ PLATYHELMINTHES } \\
\hline Turbellaria $\cdots$ & $?$ & & \\
\hline
\end{tabular}


Kendall's rank correlation coefficient, tau(b), in which ties are considered (Kendall 1962), was calculated for abundances of species pairs at each station to determine the degree of association between dominant species. Partial correlation coefficients were calculated from Kendall's tau to determine if correlations were due to interaction with a third species (Siegel 1956).

\section{RESULTS}

\section{Patterns of abundance}

The list of species collected in the Palo Alto mudflat during our study (Table 1) provides striking evidence of the importance of species introductions to San Francisco Bay. Among the 15 species identified as 'com- mon' (present in nearly every sample), only 1 species, Macoma balthica, is native to Pacific West coast estuaries. Most of the less-common species are also introduced (Carlton 1979a, b). Three of the species listed as 'common', the small suspension-feeding venerid clam Gemma gemma, the tube-dwelling suspension/deposit feeding gammarid amphipod Ampelisca abdita ( $=A$. milleri in previous reports on San Francisco Bay: Carlton 1979a), and the tube-dwelling surface deposit-feeding spionid polychaete Streblospio benedicti, comprise the vast majority of total individuals in this community (Fig. 2). All other species combined usually represent only a small percentage of the total invertebrate specimens in the mudflat. Among these, the amphipods Corophium acherusicum and Grandidierella japonica, the ostracods Sarsiella zostericola and Cyprideis sp., the polychaetes Eteone

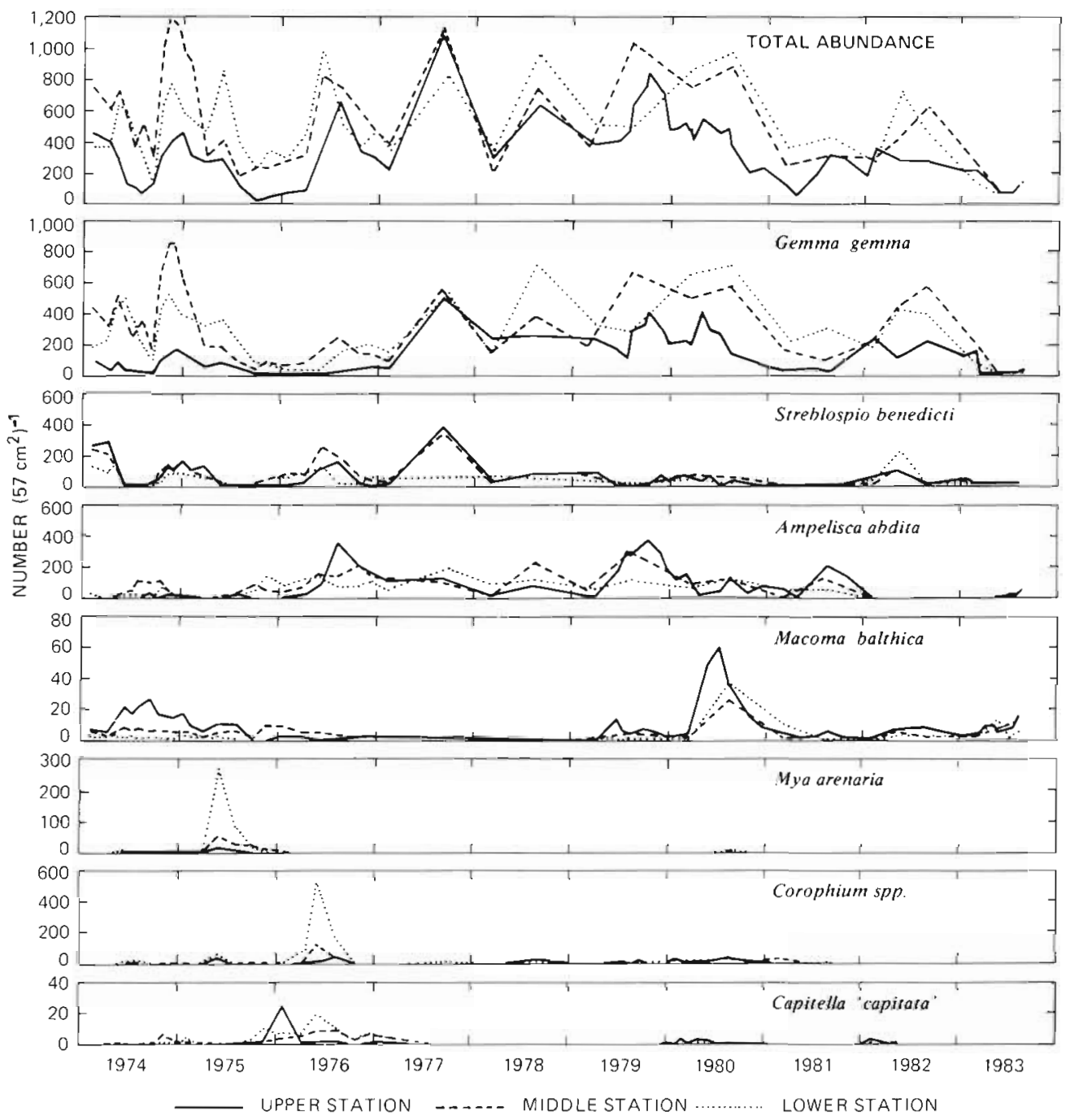

Fig. 2. Total mean abundance of specimens collected in all core samples $\left.\left(165 \mathrm{~cm}^{2} \text { samples normalized to } 57 \mathrm{~cm}\right)^{2}\right) ;$ mean abundances of the 3 numerically dominant introduced species (Gemma gemma, Streblospio benedicti, Ampelisca abdita); of the native species accounting for largest percentage of biomass (Macoma balthica); and of 3 irruptive species (Mya arenaria, Corophium spp., Capitella 'capitata') 
californica and Heteromastus filiformis, and the oligochaetes Tubificoides brownae and Limnodriloides monothecus are common but nearly always in low abundance.

Several other species (e.g. the soft-shelled clam $M y a$ arenaria at the lower station in 1975, the amphipods Corophium spp. at the middle and lower stations in 1976, the polychaete Capitella 'capitata' at the upper station in 1976, and the native mollusk Macoma balthica at all stations in 1980) exhibited occasional irruptions, but only the first 2 accounted for quantitatively important increases in total community abundance not associated with the 3 dominants (Fig. 2). Two polychaetes, Polydora ligni and Pseudopolydora kempi, were present, with occasional exceptions, only during the period 1974-76, and a third, Nereis (Neanthes) succinea, has been present only since 1976. The mudsnail Ilyanassa obsoleta is a consistent member of the community, but it occurs too infrequently in our core samples $\left(<<1\right.$ core $^{-1}$ ) to permit an evaluation of seasonal or annual fluctuations. The remaining species listed in Table 1 appeared occasionally in very low numbers.

Species composition showed a marked degree of constancy at all stations through the $10 \mathrm{yr}$ sampling period. In the test of community persistence, Kendall's coefficient of concordance $W$ was highly significant at all stations: upper station, $\mathrm{W}=0.456(\mathrm{p}<0.001$, d.f. $=40) ;$ middle station, $W=0.582 \quad(p<0.001$, d.f. $=39)_{;}$lower station, $W=0.603 \quad(\mathrm{p}<0.001$, d.f. $=39$ ). That is, the ranking of species by abundance did not vary significantly over the study period.

Inverse classification, in which the degree of similarity among the species is determined on the basis of their co-occurrence in the samples, revealed a primary core group of closely associated species common to all 3 stations: Gemma gemma, Streblospio benedicti, Ampelisca abdita, Macoma balthica lexcept at the lower station), Heteromastus filiformis, and Eteone californica (Fig. 3). The Oligochaeta, lumped as a single taxon because not all of the individuals have been identified, was also a member of the core group. Chained onto the core group at a lower level of similarity, and only at the upper and middle stations, was a secondary group consisting of Grandidierella japonica, Sarsiella zostericola, Boonea sp., Corophium spp. (females of $C$. acherusicum and $C$. insidiosum which are indistinguishable), and Mya. At the lower station the secondary species group was ill-defined. As discussed below, the predominance of the primary core group during the study period was interrupted only during major habitat disturbance events.

In addition to the similarity in species composition among stations, there was, for each species, a high degree of coincidence among the stations in the timing of abundance fluctuations: between-station cross-correlation analysis of the abundance data collected during the first $3 \mathrm{yr}$ of the study for the 3 numerically dominant species, Ampelisca abdita, Streblospio benedicti and Gemma gemma, resulted in highly significant correlation coefficients in all pairwise combinations of stations (range of ' $r$ ' correlation coefficients: G. gemma, 0.777 to 0.831 ; A. abdita, 0.447 to 0.816 ; . benedicti, 0.759 to $0.924 ; 95 \%$ confidence level $=0.395, \mathrm{n}=25$ ).

The community is, however, characterized by very large within- and between-year abundance fluctuations. Abundance of Ampelisca abdita, Streblospio benedicti, and Gemma gemma usually peaked during the seasonal recruitment of juveniles to the population. However, only $A$. abdita abundance varied on a seasonally predictable basis from year to year. $A$. abdita achieved peak abundances greater than $20,000 \mathrm{~m}^{-2}$, and occasionally greater than $60,000 \mathrm{~m}^{-2}$ in summer and autumn, reflecting the occurrence of 2 generations each year: an overwintering generation that reproduces in spring, and the resulting generation that reproduces in mid- to late-summer (Kinnetic Laboratories Inc. 1983). A least-squares regression, in which all $A$. abdita data were fitted to a sinusoidal curve with a length of $1 \mathrm{yr}$, showed that the amplitude of the annual abundance cycle was significantly different from zero at the $95 \%$ confidence level and that the timing of peak abundance (average in Oct) was consistent from year to year (Fig. 4). Amplitudes of average annual abundance curves generated for $S$. benedicti and $G$. gemma were not significantly different from zero at the $95 \%$ confidence level. This is the case because, in both species, the time of maximum abundance during 1 yr could be the time of minimum abundance during another year (Fig. 4). High densities of $G$. gemma, occasionally exceeding $400,000 \mathrm{~m}^{-2}$ in midsummer when the number of juveniles peaked, were achieved by the long breeding season and the ability of females to have 2 or more broods each year (Thompson 1982). These characteristics spread the potential period of maximum abundance over many months. $S$. benedicti achieved densities up to $60,000 \mathrm{~m}^{-2}$ between autumn and spring, although juveniles were present throughout much of the year (see also Jones 1961). It is clear that $G$. gemma and $S$. benedicti abundance fluctuations are driven by factors other than the simple passing of climatic seasons.

\section{Disturbance events}

The major changes in the mudflat community during our study occurred as a result of discrete disturbances of the habitat. For example, a decline in abundance of 


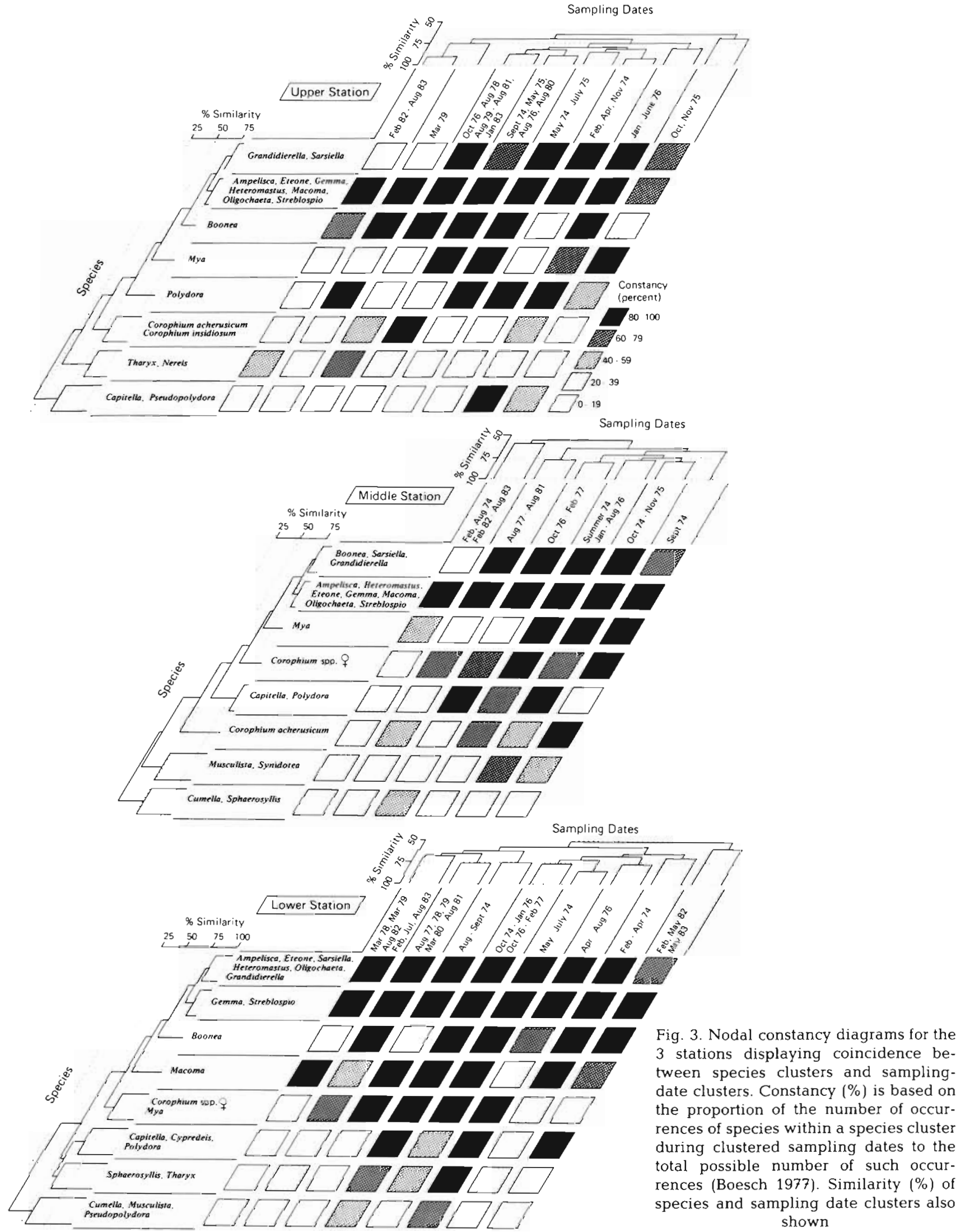


Gemma gemma and total macrofaunal abundance between July and August 1974 (Fig. 2 \& 5) coincided with the erosion of about 6 to $8 \mathrm{~cm}$ of sediment from the mudflat surface in the study area. This event, most apparent at the middle and lower stations, is clearly defined by the nodal analysis (Fig. 3), but the core group of species was not displaced. The abundances of Ampelisca abdita and Streblospio benedicti, already low during this period, were not noticeably affected, and the larger clam Macoma balthica seemed unaffected. We surmise that G. gemma and other small, surface-dwelling animals (e.g. species of Sarsiella, Cyprideis, Polydora) were removed by the same scouring action that removed the sediment, while the deeper burrowing $M$. balthica remained. Recovery of G. gemma as well as a resurgence of $S$. benedicti in autumn was rapid (Fig. 5), undoubtedly because juveniles of these species are plentiful at that time of year, and the physical nature of the newly exposed surface sediments was not unlike that which was eroded (Thompson 1979).

A much more severe disturbance resulted from the deposition in August 1975, and subsequent decay, of a thick (up to $40 \mathrm{~cm}$ high) mat of the macroalga Polysiphonia $\mathrm{sp}$. that covered a large portion of the upper intertidal at our study site. The resulting anoxia at the sediment surface eliminated nearly all of the infauna at the upper station, including Macoma balthica, and was coincident with reduced densities at the other 2 stations as well (Fig. 5). Complete dispersal of the decaying algal material required several months. As a result, the benthic community was slow to recover, particularly because the decaying algae remained on the mudflat during the period of maximum juvenile availability. Recovery may have been additionally affected by the bromophenols contained in Poly. siphonia sp. tissue that are toxic to microalgae (McLachlan \& Craigie 1966, Fenical 1975): algae that grow on the mudflat surface provide a major source of food for the invertebrates. The period of algal mat decay and the subsequent return to a normal condition were clearly defined by nodal analysis of upper station data in the decline and return to prominence of the primary core group of species (Fig. 3). Ampelisca abdita and Streblospio benedicti regained typical densities at the most disturbed inshore site during the following summer (Fig. 5). G. gemma, on the other hand, required 2 yr to resume its role as the numerical dominant, and $M$. balthica did not become abundant again until 1979 (Fig. 2).

Recovery from the algal mat die-off also featured irruptions of several species that are normally very
Fig. 4. Abundance of the 3 numerically dominant species over a $10 \mathrm{yr}$ period (straight lines), and computed average annual abundance cycles from least-squares regressions of data (curvilinear lines) at upper, middle, and lower intertidal stations

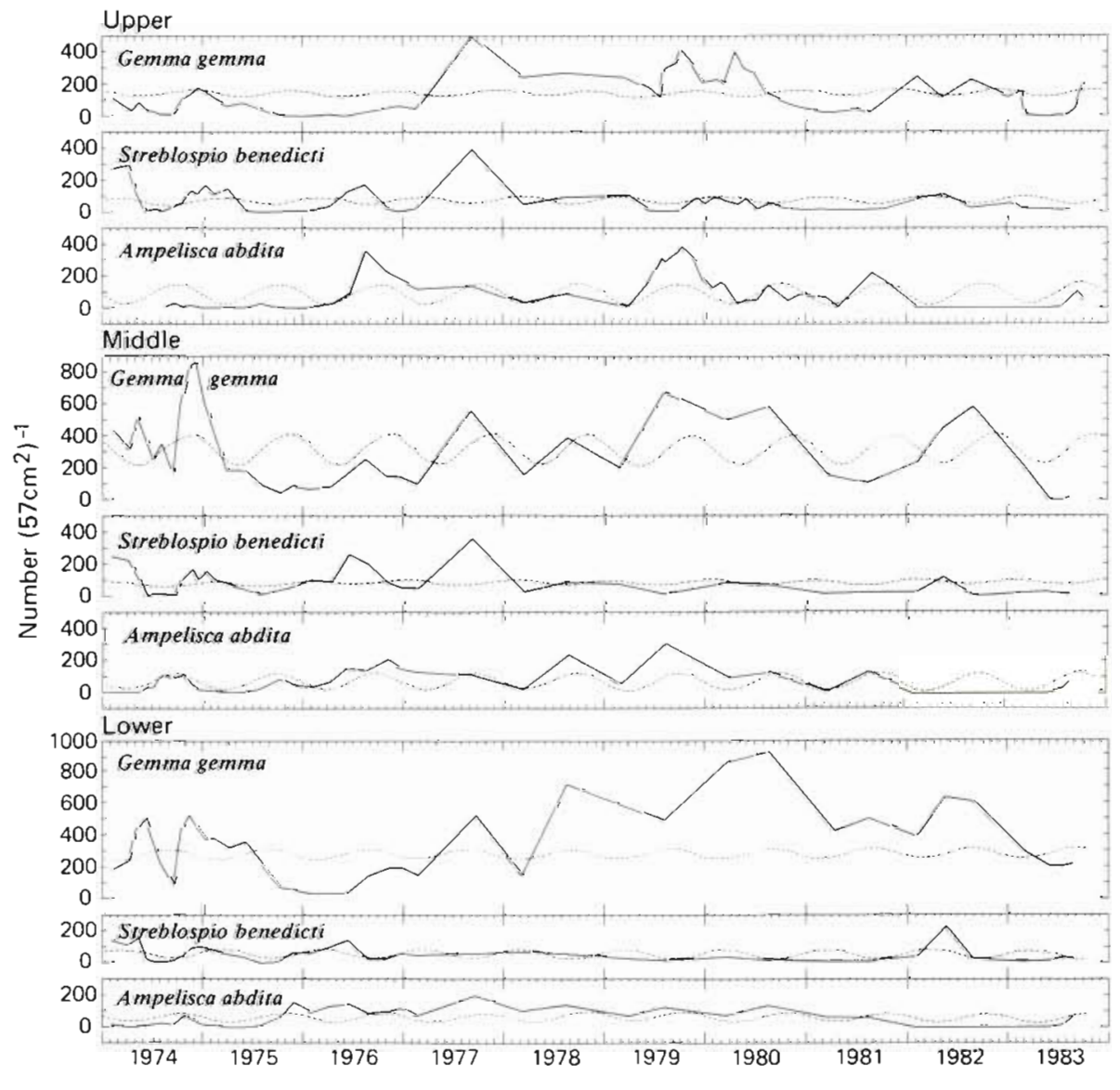




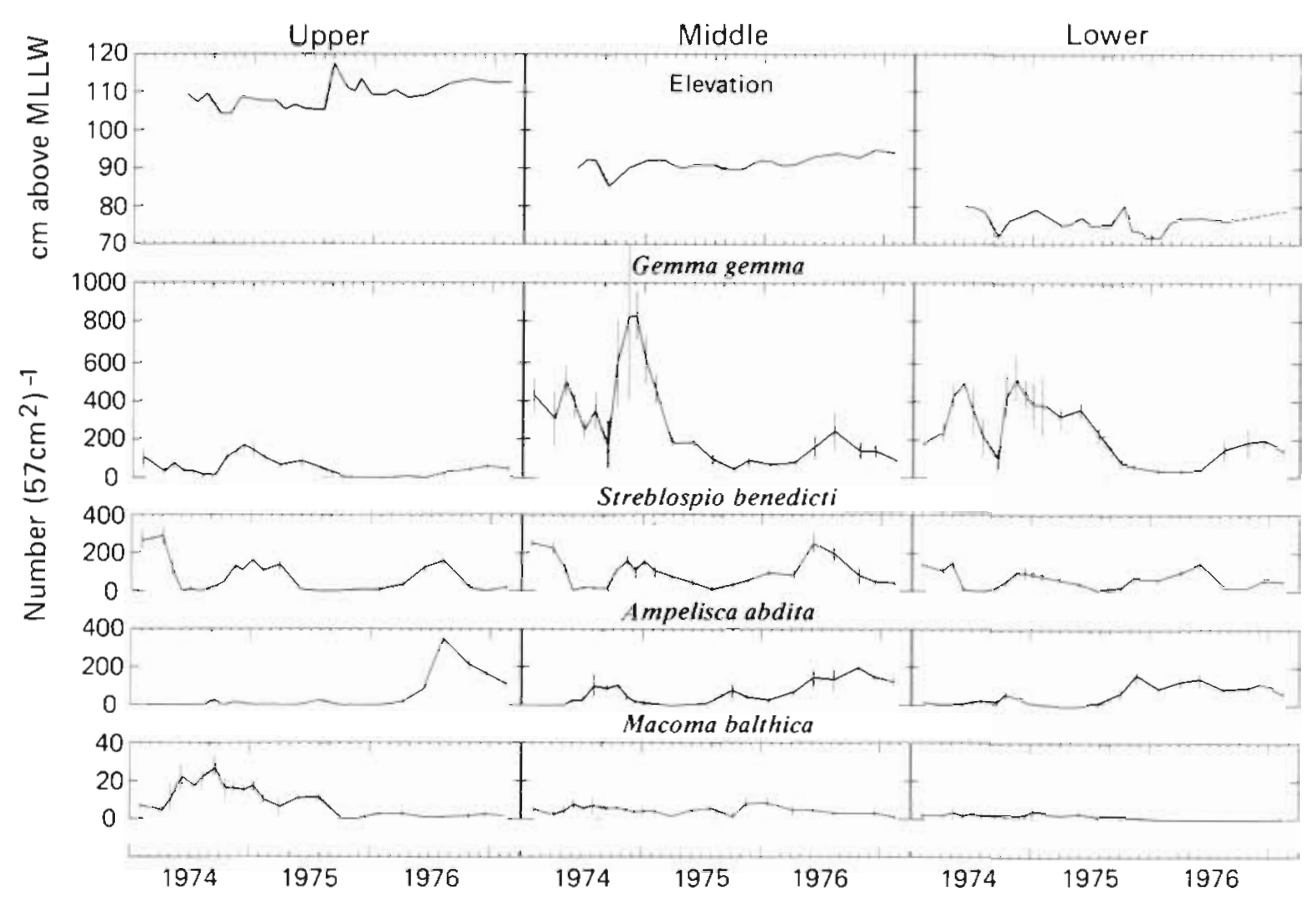

Fig. 5. Elevation of mudflat surface above mean lower low water, and mean abundance ( \pm 1 SD) of Gemma gemma, Streblospio benedicti, Ampelisca abdita, and Macoma balthica at 3 sampling sites between Feb 1974 and Feb 1977. Shaded bars: mudflat erosion (1974) and algal mat die-off (1975) events

minor members of the community, contributing to the separation of this period in the cluster analysis (Fig. 3). At this time the polychaetes Sphaerosyllis $\mathrm{sp}$. and Pseudopolydora kempi, the ostracod Sarsiella zostericola, and the amphipod Corophium acherusicum, all reached the highest levels observed during the study. The irruption of $C$. acherusicum at the lower station (Fig. 2) was particularly marked despite the fact that this station seemed least affected by the algae.

The only 'fugitive' species to appear in appreciable numbers (about 4,000 $\mathrm{m}^{-2}$ ) was Capitella 'capitata', an opportunistic polychaete renowned for responding to disturbed environments (Grassle \& Grassle 1974) but seldom seen at our study site. Interestingly, this modest irruption (Fig. 2) occurred nearly 6 mo after the die-off, in contrast to observations of more rapid response elsewhere (e.g. Sanders et al. 1980, Dauer 1984). A large increase in the mean body size of C. 'capitata' accompanied the increase in numbers. These simultaneous changes could reflect the increased food resources available to $C$. 'capitata' in the underpopulated sediments, but may also signal the appearance of a morphologically similar but genetically distinct sibling species (characteristic for this taxon: Grassle \& Grassle 1976) not seen previously or since in our samples.

During recolonization of the upper station, juveniles of each species were the most abundant among the first arrivals. Nonetheless, about $20 \%$ of the Ampelisca abdita collected between October 1975 and January 1976 were adults (the same ratio of juveniles to adults as in the population at the nearby middle station). When the Gemma gemma population began to recover 1 yr later, about $24 \%$ were specimens older than 1 yr (Thompson 1979). These observations show that lateral migration of adults as well as juveniles is an important mechanism of recolonization following disturbances. Initial recolonization of the upper station by Streblospio benedicti involved small-sized individuals only, however.

A major community change again occurred during winter 1982 when Ampelisca abdita disappeared from our study area and remained absent until late summer 1983 (Fig. 6). Further, in spring 1983 Gemma gemma and Streblospio benedicti were also reduced to unusually low numbers (Fig. 2). These changes, delineated in the cluster analysis and associated with the disappearance of some of the secondary species as well (Fig. 3), occurred during 2 of the wettest years in recent history when high river flow occurred over an unusually long period between early winter and late spring. The fresh-water inflow and low salinity (Fig. 6), and perhaps the accompanying high turbidity and the observed deposition of fine terrigenous mud, may have affected these species. On the other hand, Macoma balthica - a species tolerant of low salinities (own obs.) - was abundant on the mudflat during this long period (Fig. 6). 
Fig. 6. Average daily flow of fresh water into San Francisco Bay from Sacramento/ San Joaquin River system (California Dept. of Water Res. unpubl.); near-surface salinity collected at a mid-channel site in South San Francisco Bay (US Geol. Surv. unpubl.); mean abundances of $\mathrm{Am}^{-}$ pelisca abdita and Macoma balthica at 3 intertidal sites

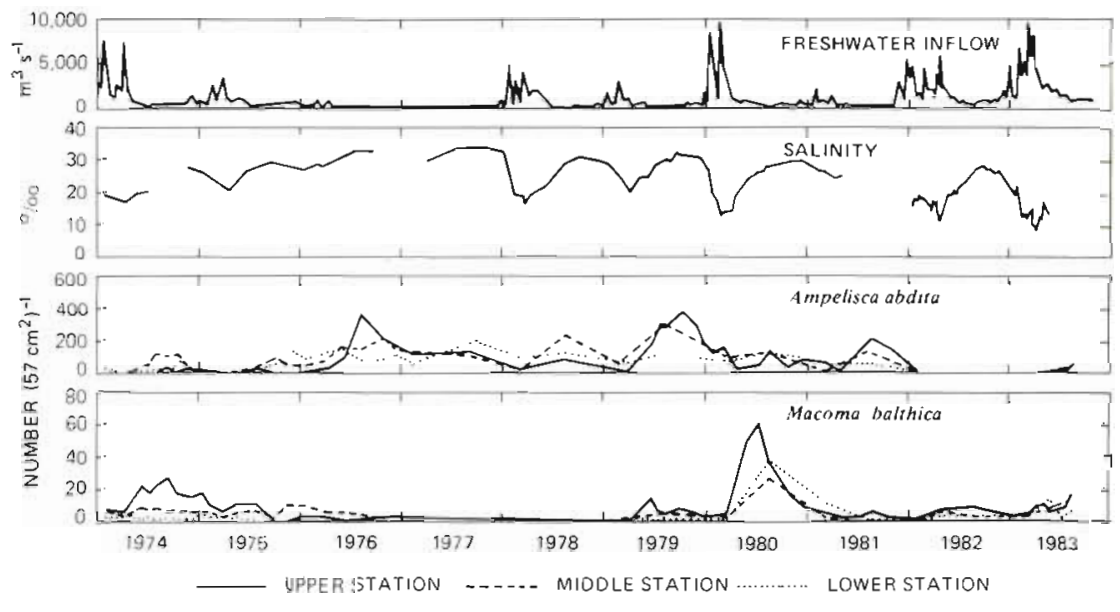

\section{DISCUSSION}

The benthic community of the South San Francisco Bay mudflat has demonstrated a high degree of persistence (sensu Connell \& Sousa 1983) during the 10 yr of our study despite large changes in the abundance of the common species: (1) species composition and relative abundance rankings among species have demonstrated a high degree of constancy; (2) total community abundance has fluctuated widely but within finite bounds (i.e. there is no indication of a long-term trend in abundances of common species or in total abundance). Only during the 2 periods of major physical perturbation were the populations of common species observed to become locally extinct. And only during the algal mat die-off were resident species replaced, in a more typical process of succession following disturbance (see 'Introduction'), by species not normally abundant in the community. Following both of these perturbations the normally dominant species reappeared within the time span required for 1 turnover of all individuals in those populations (as required by Connell \& Sousa's (1983) definition of persistence).

What has allowed a small group of introduced opportunists to become established and maintain themselves in permanent populations on the mudflat? It seems that the answer lies in the compatibility of their opportunistic life styles with the periodic disturbance of their habitat. The members of this community are able to respond to local habitat disturbance through rapid recolonization by both juveniles and adults. Because the time scale of these responses is rapid (weeks to months), the establishment of longer-lived equilibrium' species is apparently not possible. These observations support the contention by Huston (1979) that under conditions of frequent disturbance, only those species with a high population growth rate can be maintained. In our case, the habitat undergoes routine disruption of varying intensity and frequency, leading to frequent 'population reductions' (Huston 1979), thus maximizing the success of short-lived opportunists. The fact that the disturbances are felt simultaneously over a wide area of the bay's mudflat habitat (i.e. there is no refuge in local patches of differing sedimentologic or hydrologic regimes) also tends to result in reduced diversity ('environmental phasing'; Abugov 1982). Thus, the same characteristics of introduced species that permitted their successful introduction (tolerance of a wide range of physical and chemical environmental conditions, and opportunistic lifestyles) have insured their success on South San Francisco Bay mudflats and the exclusion of longer-lived equilibrium' species.

\section{Habitat disturbance and opportunism}

In addition to the changes in sediment texture and relief at our mudflat study site observed during the 3 yr period of near-monthly sampling at the beginning of our study, we have continued to observe alternations between a mud surface without relief to one of low ridges and troughs with a vertical relief of 1 to $3 \mathrm{~cm}$ and a distance between crests of about 10 to $20 \mathrm{~cm}$. Periodically, and generally during winter, fluid mud fills the troughs leaving a surface without relief. Such observations suggest to us that disturbances important to the behavior and local survival of mudflat invertebrates are routine. Sediment erosion, transport, and deposition, sedimentation of river-borne material, and fluctuating salinity all occur routinely, but with greatly varying frequency and intensity.

The life-history characteristics of the dominant species, well known from studies of US East Coast populations (Gemma gemma: Sellmer 1959, Green \& Hobson 1970; Ampelisca abdita: Mills 1967; Streblospio benedicti: Dean 1965, Watling 1975, Whitlatch 1977, Dauer et al. 1981), are clearly suited to these 
conditions. The long reproductive season of G. gemma (Mar through Oct) permitted by the mild San Francisco Bay climate, for example, allows females to have 2 or more broods each year (Thompson 1982). G. gemma releases its young fully ready to inhabit the sediments alongside the adults and, because it lives at the sediment surface, is readily suspended and transported with sediment particles by wave and current action (Sanders et al. 1962, Gilbert 1969, Whitlatch 1977 , Thompson 1982). Both juveniles and adults are thus recruited to our sampling sites (Thompson 1982). Development in $A$. abdita is also direct, with juveniles leaving the brood pouch after about 2 wk (Mills 1967). Both juveniles and adults migrate to and from the mudflat. S. benedicti releases its young either as feeding larvae in the plankton for a variable period (Dean 1965), or as non-feeding larvae that settle upon release (Levin 1981, 1984b). As is true for the other dominants in San Francisco Bay, all stages of reproductive maturity in $S$. benedictican be found throughout much of the year (Jones 1961).

The advantages of a life-history strategy that combines multiple generations each year, brood protection, ease of dispersal (pelagic or benthic larvae that can be transported by tide-, wind-, or density-driven circulation) in an estuary characterized by large-scale lateral water movement (because of shallow depth and large tidal range) are clear: near-continuous dispersal and recolonization of disturbed areas are possible (Grassle \& Grassle 1974, Gray 1979). Under these conditions, local 'mortality' may simply represent temporary departures of the animals during times of stress. Other data from San Francisco Bay suggest, for example, that Ampelisca abdita may find initial refuge from inundation by low salinity water during winter by migrating to sediments in deeper water (Nichols \& Thompson 1985).

The San Francisco Bay mudflat community appears to reflect, therefore, a balance between life-history strategy and environmental predictability (cf. Green 1969) that allows a group of species to persist. Wolff et al. (1977) and Santos \& Simon (1980) have noted a similar balance in the soft-bottom benthos elsewhere.

\section{Number of species in the mudflat community}

The total number of species in the Gemma, Ampelisca, Streblospio community of San Francisco Bay mudflats is lower than that found in the equivalent community of the eastern United States (e.g. Rehobeth Bay: Watling 1975; Barnstable Harbor: Whitlatch 1977). This may result from a combination of 2 factors: the smaller pool of potential colonizers, and the textural uniformity of the bay's shallow-bottom sediments.
Estuaries typically have fewer benthic species than oceans (Wolff 1983), largely because of the unstable and unpredictable nature of the estuarine environment (Sanders 1968, Slobodkin \& Sanders 1969). Moreover, the San Francisco Bay estuary (like those of northwestern Europe; Wolff 1972) has a small number of native species owing to its relative geologic youth (less than 10,000 yr; Atwater et al. 1979) and its geographic (and faunistic) isolation from other estuaries (Jones 1940, Hedgpeth 1968, Carlton 1979a, b). Moreover, most of the Bay's broad intertidal and shallow subtidal is covered with soft mud with little vertical relief. As such, this habitat is suitable only to a limited number of benthic species, and pools of potential colonizers not normally part of this community are presumably small and well removed from the mudflats. In contrast, estuaries of the eastern United States are geologically older, more closely spaced and often interconnected, and with more diverse sedimentary regimes.

A community composed of few species can persist over the long term if the species, as habitat generalists, are tolerant of a wide range of environmental conditions and are broadly distributed (Jackson 1974, Persson 1983). These characteristics permit resident species to reestablish their populations following local disturbances, particularly if the number of potential exploiter/recolonizer species that are not routinely a part of the community is small. The species introduced to San Francisco Bay were highly successful because, as habitat generalists and opportunists, they exploited a habitat to which few native species were similarly adapted, or outcompeted native species that formerly inhabited it. Race (1982) has shown, for example, that the native hornsnail Cerithidea californica is restricted in its habitat range to marsh pans through competitive interaction and predation by the introduced mudsnail Ilyanassa obsoleta. The implication is that, prior to the arrival of the introduced species, the range of the native species extended to the open mudflats.

\section{Species interactions}

The 3 numerical dominants routinely coexist at high densities, occasionally exceeding a cumulative total of 150,000 adults $\mathrm{m}^{-2}$ during summer. A comparison of the densities of species pairs within individual $57 \mathrm{~cm}^{2}$ core samples (Fig. 7A, B, C), using Kendall's rank correlation coefficient tau, provided no indication that any one of the numerically dominant species has a negative influence on the abundance of the other two. In fact, the ranks of Gemma gemma and Streblospio benedicti are highly correlated (Fig. $7 \mathrm{C}$ ). Computation of Kendall's partial rank correlation coefficients showed further that these species-pair relationships 

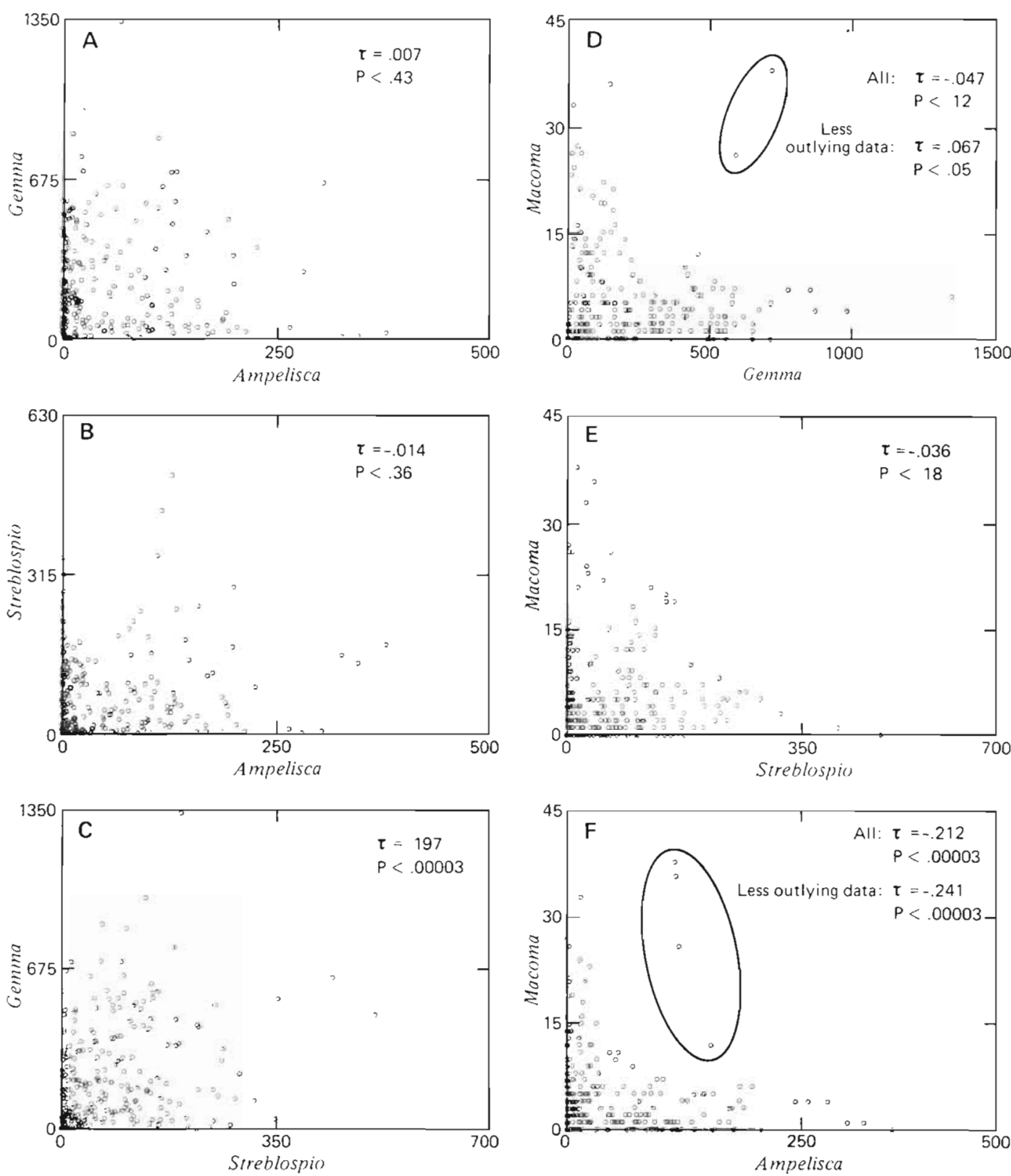

Fig. 7. Within-core $\left(57 \mathrm{~cm}^{2}\right)$ densities of species pairs. Outlying data in D and F (circled): observations made in Aug 1974 and Aug 1980 following successful spring recruitment of Macoma balthica in the relative absence of Ampelisca abdita; $\tau$; Kendall's rank correlation coefficient tau (with probabilities) (with and without outlying data in D and F)

were not affected by interactions with a third species (including Macoma balthica). On the other hand, Mills (1967) and Santos \& Simon (1980) suggested that Ampelisca abdita at high densities does interfere with $S$. benedicti feeding, while Levin (1981) and Dauer et al. (1981) showed that $S$. benedicti is non-aggressive in the face of competition for space.

It appears that brooding could be involved in the ability of these species to co-occur at high densities. With the exception of a brief appearance of Mya arenaria in 1975 (Fig. 8, outlying data), the contribu- tion of non-brooding species to total abundance was insignificant when densities in our cores increased above about 300 to 400 individuals (Fig. 8). The dense co-occurrence of Gemma gemma, Ampelisca abdita, and Streblospio benedicti may be facilitated by brooding of young if, for example, the juveniles of the nearsurface living species (e.g. G. gemma) escapes predation by the tube dwellers (e.g. A. abdita and $S$. benedicti) through large size (Woodin 1976). However, Weinberg (1984) showed that another tube-dwelling spionid polychaete, Polydora ligni, does consume $G$. 


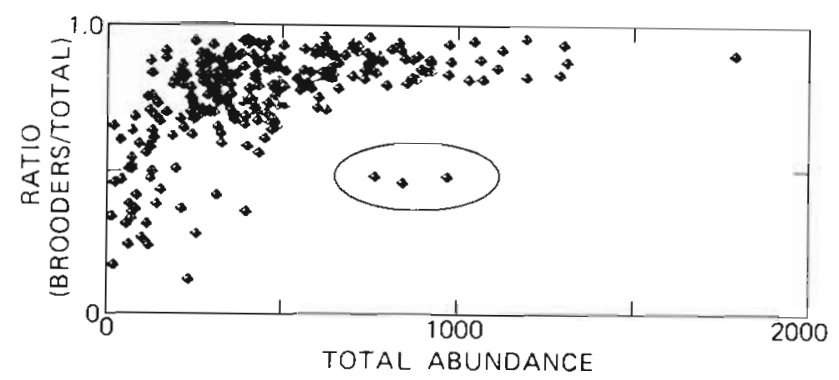

Fig. 8. Relation of the ratio (number of individuals of brooding species) / (total individuals) as a function of total individuals in our core samples. Outlying data (circled): Mya arenaria abundance in 1975

gemma juveniles and reduces adult survival. On the other hand, tube-dwelling species have been shown experimentally to facilitate the recruitment of other species in soft-bottom communities (Gallagher et al. 1983).

A comparison of within-core densities of Macoma balthica and the other species (Fig. 7D, E, F) indicated, however, that year-to-year fluctuations in $M$. balthica abundance may be related to interference. With several exceptions discussed below, $M$. balthica does not co-occur at high densities with Gemma gemma and Ampelisca abdita. Rank correlation analysis showed a highly significant negative correlation between $M$. balthica and A. abdita (Fig. 7F) and a significant negative correlation between $M$. balthica and $G$. gemma when the outlying points (discussed below) were removed from the analysis. A similar negative correlation, resulting from a cross-correlation analysis of the A. abdita and $M$. balthica data collected between 1974 and 1977 (Fig. 5), was significant at the upper and lower stations (upper: ' $r$ ' $=-0.454$; middle: -0.324 ; lower: $-0.742 ; 95 \%$ confidence level $=-0.395$, $\mathrm{n}=25$ ).

Macoma balthica is found in greatest abundance in the high intertidal, while Gemma gemma is more abundant at the lower elevations (Fig. 2; see also Vassallo 1969. Thompson 1982). Gilbert (1969) suggested that the siphon-feeding activities of $M$. balthica disturbed $G$. gemma, although she did observe that $M$. balthica actively rejected even the smallest $G$. gemma specimens when feeding. Our 1980 data (Fig. 2) indicate that it is possible for large numbers of $M$. balthica juveniles to settle in the presence of a dense G. gemma population, and that mature populations of the 2 species can co-occur. The stronger degree of nonoverlap between $M$. balthica and Ampelisca abdita (Fig. 7F) does not seem related to different preference of location within the intertidal zone: $A$. abdita, like $M$. balthica, achieves high densities in the upper intertidal. Vassallo (1969) concluded that $A$. abdita interfered with $M$. balthica settlement through predation, physical processes, or competition for food.
The largest numbers of Macoma balthica juveniles consistently appear during winter or early spring (Fig. 3; Nichols \& Thompson 1982). Our samples from 1980 (Fig. 2, upper station) show that while dense populations of $M$. balthica and Ampelisca abdita can co-occur (Fig. 7F, outlying points), they do so only when the $M$. balthica larvae settled in the relative absence of $A$. abdita (e.g. Fig. 2, spring 1980). A similar situation existed in 1974 and again during the period since early 1982 (Fig. 2). Segerstråle's (1973) 'MacomaPontoporeia theory', the inverse correlation between recruitment of $M$. balthica and abundance of the amphipod $P$. affinis in the Baltic Sea, is analogous. These findings, requiring experimental examination, provide tentative support for Vassallo's settlementinterference hypothesis and the more general inhibition hypothesis (Connell \& Slatyer 1977, Zajac \& Whitlatch 1982b)

Habitat grazing by Ilyanassa obsoleta (Mills 1967. Curtis \& Hurd 1981), even at the low densities found here $-<<1$ (core sample) ${ }^{-1}-$ increased predation by migrating shorebirds during winter (Recher 1966), by rays in summer (Nichols 1979), and by fish throughout the year undoubtedly contribute to the seasonal abundance fluctuations in this community. However, it is not yet obvious that they contribute markedly to the large-scale within- and between-year abundance fluctuations observed during this study.

As a final note, chronic, low-level contamination from waste-treatment plants may also be important to the benthic community (e.g. Luoma \& Cloern 1982). However, the effects of periodically elevated concentrations of contaminants on the behavior and survival of individuals or populations on this mudflat are not yet distinguishable from natural variation. Thus, our understanding of benthic community dynamics in this estuary, as elsewhere, will remain limited, despite years of study, until the many factors affecting natural populations can be considered simultaneously.

Acknowledgements. Our appreciation of the ubiquity of introduced species is largely a result of the work of J.T. Carlton. His research forms the basis of our understanding of which species have been introduced to the west coast of North America, when they were introduced, and the mechanisms by which they were introduced. He has freely shared his knowledge with us, has given us advice and ideas, and has corrected our nomenclature. We are particularly grateful to him for all of these services. We also thank I. G. Sohn, P. Lafollette, and P. V Dresler (with assistance from M. T. Barbour, R. O. Brinkhurst and C. Erseus) for identifying specimens from our ostracod, gastropod and oligochaete material respectively; $P$. A. Jumars for suggesting several approaches to the numerical analysis of the data; and M. A. Noble for much assistance in carrying out these numerical analyses. J. T. Carlton, J. W Chapman, D. D. Hardin, P. A. Jumars, S. N. Luoma, M. L. Quammen and an anonymous reviewer provided critical reviews of earlier drafts of this paper. 


\section{LITERATURE CITED}

Abugov, R. (1982). Species diversity and phasing of disturbance. Ecology 63: 289-293

Atwater, B. F., Conard, S. G., Dowden, J. N., Hedel, C. W. MacDonald, R. L., Savage, W. (1979). History, landforms and vegetation of the estuary's tidal marshes. In: Conomos, T. J. (ed.) San Francisco Bay: the urbanized estuary. Pacif. Div., Am. Ass. Adv. Sci., San Francisco, Calif., p. $347-385$

Bendat, J. S., Piersol, A. G. (1971). Random data: analysis and measurement procedures. Wiley-Interscience, New York

Beukema, J. J. (1979). Biomass and species richness of the macrobenthic animals living on a tidal flat area in the Dutch Wadden Sea: effects of a severe winter. Neth. J. Sea Res. 13: 203-223

Beukema, J. J. (1982). Annual variation in reproductive success and biomass of the major macrozoobenthic species living in a tidal flat area of the Wadden Sea. Neth. J. Sea Res. 16: $37-45$

Bloom, S. A. (1981). Similarity indices in community studies: potential pitfalls. Mar. Ecol. Prog. Ser. 5: 125-128

Bloom, S. A., Santos, S. L., Field, J. G. (1977). A package of computer programs for benthic community analysis. Bull. mar. Sci. 27: 577-580

Boesch, D. F. (1977). Application of numerical classification in ecological investigations of water pollution. Virginia Inst. Mar. Sci. Spec. Sci. Rep. 77. U.S. Environ. Protect. Agency (EPA-600/3-7703), Corvallis, Oregon

Boesch, D. F., Diaz, R. J., Virnstein, R. W. (1976a). Effects of tropical storm Agnes on soft-bottom macrobenthic communities of the James and York estuaries and the lower Chesapeake Bay. Chesapeake Sci. 17: 246-259

Boesch, D. F., Rosenberg, R. (1982). Response to stress in marine benthic communities. In: Barrett, G. W., Rosenberg, R. (ed.) Stress effects on natural ecosystems. Wiley, New York, p. 179-200

Boesch, D. F., Wass, M. L., Virnstein, R. W. (1976b). The dynamics of estuarine benthic communities. In: Wiley, $M$ (ed.) Estuarine processes, Vol. I. Academic Press, New York, p. 177-196

Bray, J. R., Curtis, J. T. (1957). An ordination of the upland forest communities of southern Wisconsin. Ecol. Monogr. 27: $325-349$

Brownlee, K. A. (1965). Statistical theory and methodology in science and engineering, 2nd ed. Wiley, New York

Buchanan, J. B., Sheader, M., Kingston, P. F. (1978). Sources of variability in the benthic macrofauna off the south Northumberland coast, 1971-1976. J. mar. biol. Ass. U.K. 58: 191-209

Carlton, J. T (1979a). Introduced invertebrates of San Francisco Bay. In: Conomos, T. J. (ed.) San Francisco Bay: the urbanized estuary. Pacific Division, Am. Ass. Adv. Sci., San Francisco, Calif., p. 427-444

Carlton, J. T. (1979b). History, biogeography, and ecology of the introduced marine and estuarine invertebrates of the Pacific coast of North America. Ph. D. thesis, Univ. California, Davis

Chapman, J. W., Dorman, J. A. (1975). Diagnosis, systematics and notes on Grandidierella japonica (Amphipoda: Gammaridae) and its introductions to the Pacific coast of the United States. Bull. Sth. Calif. Acad. Sci. 74: 104-108

Connell, J. H., Slatyer, R. O. (1977). Mechanisms of succession in natural communities and their role in community stability and organization. Am. Nat. 111: 1119-1144

Connell, J. H., Sousa, W. P. (1983). On the evidence needed to judge ecological stability or persistence. Am. Nat. 121 $789-824$
Curtis, L. A., Hurd, L. E. (1981). Nutrient procurement strategy of a deposit-feeding estuarine neogastropod, $I l y$ anassa obsoleta. Estuar. coast. Shelf Sci. 13: 277-285

Dauer, D. M. (1984). High resilience to disturbance of an estuarine polychaete community. Bull. mar. Sci. 34: $170-174$

Dauer, D. M., Maybury, C. A., Ewing, R. M. (1981). Feeding behavior and general ecology of several spionid polychaetes from the Chesapeake Bay. J. exp. mar. Biol. Ecol. 54: 21-38

Dean, D. (1965). On the reproduction and larval development of Streblospio benedicti Webster. Biol. Bull. mar. biol. Lab., Woods Hole 128: 67-76

Diaz, R. J (1984). Short term dynamics of the dominant annelids in a polyhaline temperate estuary. Hydrobiologia 115: 153-158

Eagle, R. A. (1975). Natural fluctuations in a soft bottom benthic community. J. mar. biol. Ass. U.K. 55: 865-878

Fenical, W. (1975). Halogenation in the Rhodophyta - a review. J. Phycol. 11: 245-259

Filice, F. P. (1958). Invertebrates from the estuarine portion of San Francisco Bay and some factors influencing their distributions. Wasmann J. Biol. 16: 159-211

Gallagher, E. D., Jumars, P. A., Trueblood, D. D. (1983). Facilitation of soft-bottom benthic succession by tube builders. Ecology 64: 1200-1216

Gilbert, M. A. (1969). Environmental and interspecific interactions of Gemma gemma, Mya arenaria, and Macoma balthica as revealed by density and abundance patterns, M. S. Thesis, Univ. Massachusetts, Amherst

Grassle, J. F., Grassle, J. P. (1974). Opportunistic life histories and genetic systems in marine benthic polychaetes. J. mar. Res. 32: 253-284

Grassle, J. P., Grassle, J. F. (1976). Sibling species in the marine pollution indicator Capitella (Polychaeta). Science 192: $567-569$

Gray, J. S. (1979). Pollution-induced changes in populations. Phil. Trans. R. Soc. 286: 545-561

Green, R. H. (1969). Population dynamics and environmental variability. Am. Zool. 9: 393-398

Green, R. H., Hobson, K. D. (1970). Spatial and temporal structure in a temperate intertidal community, with special emphasis on Gemma gemma (Pelecypoda: Mollusca). Ecology 51: 999-1011

Hanna, G D. (1966). Introduced mollusks of western North America. Occ. Pap. Calif. Acad. Sci. 48: 1-108

Hedgpeth, J. W. (1968). Bay and estuary (introduction). In: Ricketts, E. F., Calvin, J., Hedgpeth, J. W. (ed.) Between Pacific tides, 4 th ed. Stanford Univ. Press, Stanford, Calif., p. 231-233

Holland, A. F., Mountford, N. K., Mihursky, J. A. (1977). Temporal variation in upper bay mesohaline benthic communities: I. The 9-m mud habitat. Chesapeake Sci. 18: $370-378$

Huston, M. (1979). A general hypothesis of species diversity. Am. Nat. 113: 81-101

Jackson, J. B. C. (1974). Biogeographic consequences of eurytopy and stenotopy among marine bivalves and their evolutionary significance. Am. Nat. 108: 541-560

Jones, L. L. (1940). An introduction of an Atlantic crab into San Francisco Bay. Proc. 6th Pacif. Sci. Congr. Pacif. Sci. Ass. 3: 485-486

Jones, M. L. (1961). A quantitative evaluation of the benthic fauna off Point Richmond, California. Univ. Calif. Publs Zool. 67: 219-320

Kendall, M. G. (1962). Rank correlation methods. Charles Griffin, London 
Kinnetic Laboratories Inc. (1981). Chapter V - Benthic community analysis. Final Report, Predischarge Monitoring Program. East Bay Dischargers Authority, San Lorenzo, Calif.

Kinnetic Laboratories, Inc. (1983). Life history analysis of Ampelisca milleri. Final Report, Predischarge Monitoring Program. East Bay Dischargers Authority, San Lorenzo, Calif.

Kornicker, L. S. (1975). Spread of ostracods to exotic environs on transplanted oysters. Bull. Am. Paleont. 65: 129-139

Levin, L. A. (1981). Dispersion, feeding behavior and competition in two spionid polychaetes. J. mar. Res. 39: 99-117

Levin, L. A. (1984a). Life history and dispersal patterns in a dense infaunal polychaete assemblage: community structure and response to disturbance. Ecology 65: 1185-1200

Levin, L. A. (1984b). Multiple patterns of development in Streblospio benedicti Webster (Spionidae) from three coasts of North America. Biol. Bull. mar. biol. Lab., Woods Hole 166: 494-508

Liu, D. H. W., Martin, K. D., Norwood, C. R. (1975). San Francisco Bay benthic community study - technical evaluation, final report. Appendix D, biological community study, U.S. Army Corps of Engineers dredge disposal study, San Francisco Bay and estuary. San Francisco, Calif

Luoma, S. N., Cloern, J. E. (1982). The impact of waste-water discharge on biological communities in San Francisco Bay. In: Kockelman, W. J., Conomos, T. J., Leviton, A. E. (ed.) San Francisco Bay - use and protection. Pacif. Div., Am. Ass. Adv. Sci., San Francisco, Calif., p. 137-160

McCall, P. L. (1977). Community patterns and adaptive strategies of the infaunal benthos of Long Island Sound. J. mar. Res. 35: 221-266

McCall, P. L. (1978). Spatial-temporal distributions of Long Island Sound infauna: the role of bottom disturbance in a nearshore marine habitat. In: Wiley, M. L. (ed.) Estuarine interactions. Academic Press, New York, p. 191-219

McLachlan, J., Craigie, J. S. (1966). Antialgal activity of some simple phenols. J. Phycol. 2: 133-135

Mills, E. L. (1967). The biology of an ampeliscid amphipod crustacean sibling species pair. J. Fish. Res. Bd Can. 24 305-355

Nichols, F. H. (1977). Infaunal biomass and production on a mudflat, San Francisco Bay, California. In: Coull, B. C (ed.) Ecology of marine benthos. Belle W. Baruch Library in Mar. Sci. 6. Univ. South Carolina, Columbia, p. 339-357

Nichols, F. H. (1979). Natural and anthropogenic influences on benthic community structure in San Francisco Bay. In: Conomos, T. J. (ed.) San Francisco Bay: the urbanized estuary. Pacif. Div., Am. Ass. Adv. Sci., San Francisco Calif, p. 409-426

Nichols, F. H., Thompson, J. K. (1982). Seasonal growth in the bivalve Macoma balthica near the southern limit of its range. Estuaries 5: 110-120

Nichols, F. H., Thompson, J. K. (1985). Time scales of change in the San Francisco Bay benthos. Hydrobiologia (in press)

Painter, R. E. (1966). Zoobenthos of San Pablo and Suisun Bays. Calif. Fish Game Fish. Bull. 133: 40-56

Pearson, T. H., Rosenberg, R. (1978). Macrobenthic succession in relation to organic enrichment and pollution of the marine environment. Oceanogr. mar. Biol. A. Rev. 16: 229-311

Persson, L.-E. (1983). Temporal and spatial variation in coastal macrobenthic community structure, Hano Bay (Southern Baltic). J. exp. mar. Biol. Ecol. 68: 277-293

Pettibone, M. H. (1954). Marine polychaete worms from Point Barrow, Alaska, with additional records from the North
Atlantic and North Pacific. Proc. U.S. natn. Mus. 103 203-356

Race, M. S. (1982). Competitive displacement and predation between introduced and native mud snails. Oecologia 54 : $337-347$

Recher, H. F. (1966). Some aspects of the ecology of migrant shorebirds. Ecology 47: 393-407

Sanders, H. L. (1968). Marine benthic diversity: a comparative study. Am. Nat. 102: 243-282

Sanders, H. L., Goudsmit, E. M., Mills, E. L., Hampson, G. R. (1962). A study of the intertidal fauna of Barnstable Harbor, Massachusetts. Limnol. Oceanogr. 7: 63-79

Sanders, H. L., Grassle, J. F., Hampson, G. R., Morse, L. S., Garner-Price, S., Jones, C. C. (1980). Anatomy of an oil spill: long-term effects from the grounding of the barge FLORIDA off West Falmouth, Massachusetts. J. mar. Res. 38: $265-380$

Santos, S. L., Simon, J. L. (1980). Response of soft-bottom benthos to annual catastrophic disturbance in a south Florida estuary. Mar. Ecol. Prog. Ser. 3: 347-355

Segerstråle, S. G. (1973). Results of bottom fauna sampling in certain localities in the Tvarminne area (inner Baltic), with special reference to the so-called Macoma-Pontoporeia theory. Commentat. biol. 67: 3-12

Sellmer, G. P. (1959). Studies on the anatomy and life history of the gem clam Gemma gemma (Totten). Ph. D. thesis, Rutgers Univ., New Brunswick, New Jersey

Siegel, S. (1956). Nonparametric statistics for the behavioral sciences. McGraw-Hill, New York

Slobodkin, L. B., Sanders, H. L. (1969). On the contribution of environmental predictability to species diversity. Brookhaven Symp. Biol. 22: 82-93

Sneath, P. H. A., Sokal, R. R. (1973). Numerical taxonomy. Freeman, San Francisco

Storrs, P. N., Pearson, E. A., Selleck, R. E. (1966). A comprehensive study of San Francisco Bay, final report. 5. Summary of physical, chemical and biological water and sediment data. Univ. Calif. (Berkeley) Sanitary Eng. Res. Lab. Rep. 63-3

Sutherland, J. P. (1974). Multiple stable points in natural communities. Am. Nat. 108: 859-873

Thistle, D. (1981). Natural physical disturbances and communities of marine soft bottoms. Mar. Ecol. Prog. Ser. 6: 223-228

Thompson, J. K. (1979). Population dynamics and sediment relations of Gemma gemma in San Francisco Bay. M. S. thesis, San Francisco State Univ., San Francisco

Thompson, J. K. (1982). Population structure of Gemma gemma in south San Francisco Bay, with a comparison to some northeastern United States estuarine populations. Veliger 24: 281-290

Thompson, J. K., Nichols, F. H. (1984). Benthic macrofauna of a South San Francisco Bay, California, mudflat, 1974 to 1983. U.S. Geol. Surv. Open File Rep. 84-759

VanBlaricom, G. R. (1982). Experimental analysis of structural regulation in a marine sand community exposed to oceanic swell. Ecol. Monogr. 52: 283-305

Vassallo, M. T. (1969). The ecology of Macoma inconspicua (Broderip and Sowerby, 1829) in central San Francisco Bay. I. The vertical distribution of the Macoma community. Veliger 11: 223-234

Watling, L. (1975). Analysis of structural variations in a shallow estuarine deposit-feeding community. $J$. exp. mar Biol. Ecol. 19: 275-313

Weinberg, J. R. (1984). Interactions between functional groups in soft-substrata: do species differences matter? J. exp. mar. Biol. Ecol. 80: 11-28 
Whitlatch, R. B. (1977). Seasonal changes in the community structure of the macrobenthos inhabiting the intertidal sand and mud flats of Barnstable Harbor, Massachusetts. Biol. Bull. mar. biol. Lab., Woods Hole 152: 275-294

Wolff, W. J. (1972). Origin and history of the brackish water fauna of N. W. Europe. In: Battaglia, B. (ed.) Fifth European mar. biol. Symp. Piccin Editore, Padova, Italy, p. $11-18$

Wolff, W. J. (1983). Estuarine benthos. In: Ketchum, B. H. (ed.) Estuaries and enclosed seas. Elsevier Sci. Publ. Co. Ansterdam, p. 151-182

Wolff, W. J., Sandee, A. J. J., de Wolf, L. (1977). The development of a benthic ecosystem. Hydrobiologia 52: 107-115
Woodin, S. A. (1976). Adult-larval interactions in dense infaunal assemblages: patterns of abundance. J. mar. Res. 34: $25-41$

Zajac, R. N., Whitlatch, R. B. (1982a). Responses of estuarine infauna to disturbance. I. Spatial and temporal variation of initial recolonization. Mar. Ecol. Prog. Ser. 10: 1-14

Zajac, R. N., Whitlatch, R. B. (1982b). Responses of estuarine infauna to disturbance. Il. Spatial and temporal variation of succession. Mar Ecol. Prog. Ser. 10: 15-27

Ziegelmeier, E. (1978). Macrobenthos investigations in the eastern part of the German Bight from 1950 to 1974. Rapp. P.-v. Réun. Cons. int. Explor. Mer 172: 432-444

This paper was presented by Dr. C. D. Levings; it was accepted for printing on April 29, 1985 